\title{
ANALISIS PENGEMBANGAN BUDAYA AKADEMIK DAN PROBLEMATIKANYA DI FAKULTAS ILMU TARBIYAH DAN KEGURUAN IAIN SULTAN AMAI GORONTALO
}

\author{
Selvi Ma'ruf \& Abdur Rahman Adi Saputera \\ Institut Agama Islam Negeri (IAIN) Sultan Amai Gorontalo \\ E-mail: selvimarufgandi@gmail.com, adisaputrabd@gmail.com
}

\begin{abstract}
Abstrak
Penelitian ini bertujuan menganalisis kendala dalam mengembangkan budaya akademik di Fakultas Ilmu Tarbiyah dan Keguruan IAIN Sultan Amai Gorontalo, Sedangkan jenis penelitian ini menggunakan gabungan metode kualitatif dan kuantitatif yang disebut mixed methods (metode campuran/kombinasi). Data kualitatif dan kuantitatif dikumpulkan untuk saling melengkapi. Hasil Penelitian menyatakan bahwa Budaya akademik FITK IAIN Sultan Amai Gorontalo berdasarkan pelaksanaan Tri dharma Perguruan. Kendala dalam mengembangkan budaya akademik di Fakultas Ilmu Tarbiyah IAIN Sultan Amai Gorontalo, yaitu faktor internal dan eksternal. Faktor internal masih terdapat dosen yang kurang disiplin terhadap frekuensi perkuliahan/tatap muka, budaya membaca dan menulis buku masih rendah baik dosen ataupun mahasiswa. Faktor eksternal, dimana sarana pendukung alat membaca buku-buku digital-e-reader di perpustakaan seperti komputer/laptop belum tersedia khusus untuk ruang baca serta minimnya pengadaan bahan pustaka baru setiap tahun.
\end{abstract}

Kata Kunci : Pengembangan, Budaya Akademik

\begin{abstract}
This study aims to analyze the constraints in developing academic culture in the Faculty of Tarbiyah IAIN Sultan Amai Gorontalo, while this type of research uses a combination of qualitative and quantitative methods called mixed methods (mixed methods/combination). Qualitative and quantitative data are collected to complement each other. The results of the study stated that the academic culture of FITK IAIN Sultan Amai Gorontalo was based on the implementation of the Tri Dharma Perguruan. Constraints in developing academic culture in the Faculty of Sciences Tarbiyah IAIN Sultan Amai Gorontalo, namely internal and external factors. Internal factors are still lecturers who lack discipline in the frequency of lectures/face to face, the culture of reading and writing books is still low both lecturers and students. External factors, where the means of supporting tools to read digital-e-reader books in libraries such as computers/laptops are not yet available specifically for reading rooms and the lack of procurement of new library materials every year.
\end{abstract}

Keywords: Development, Academic Culture 


\section{Pendahuluan}

Ilmu pengetahuan adalah harta yang paling berharga, dan pendidikan yang baik adalah warisan yang paling bermanfaat. Perubahan lingkungan dan masyarakat baik yang disebabkan oleh faktor internal maupun eksternal, termasuk dunia kerja membawa dampak pada perubahan di bidang pendidikan nasional pada umumnya dan Fakultas Ilmu Tarbiyah dan Keguruan pada khususnya. Perkembangan masyarakat yang semakin komplek menuntut Perguruan tinggi memiliki dan mengembangkan budaya akademik yang dapat membentuk mahasiswa agar memiliki jatidiri dan kompetensi dibidangnya. Menurut Tylor, sebagai mana dikutip oleh Brown dalam Koentjaraningrat bahwa budaya adalah "the complex whole which includes knowledge, belief, art, morals, law, custom, and any other capabilities and habits acquired by man as a member of society" (sekumpulan pengetahuan, keyakinan, seni, moral, hukum, adat, kapabilitas, dan kebiasaan yang diperoleh seseorang sebagai anggota sebuah perkumpulan atau komunitas tertentu). ${ }^{1}$ Dengan demikian budaya akademik berarti apa yang dipelajari oleh mahasiswa selama periode waktu tertentu dari universitas, fakultas atau jurusannya. Pengembangan budaya akademik ini didasarkan atas dua tantangan yang selalu dihadapi oleh pendidikan tinggi dalam penyelenggaraan pendidikannya yaitu tantangan yang bersifat internal dan eksternal.

Tujuan dan arah pendidikan Tinggi di Indonesia seperti yang tertuang pada Bab II pasal 2 Keputusan Menteri Pendidikan No.232/U/2000 adalah menyiapkan peserta didik untuk menjadi anggota masyarakat yang memiliki kemampuan akademik dalam menerapkan, mengembangkan, dan/atau memperkaya kasanah ilmu pengetahuan, teknologi dan atau kesenian, serta menyebarluaskan dan mengupayakan penggunaannya untuk meningkatkan taraf kehidupan dan memperkaya kebudayaan nasional. Ini berarti kinerja akademik dituntut dilaksanakan secara kompetitif dengan kualitas unggul. Kinerja akademik yang tidak berorientasi pada kualitas unggul, tidak saja akan tertinggal dalam persaingan tetapi juga akan bergantung pada dunia luar yang lebih maju.

Dalam Undang Undang nomor 12 tahun 2012 tentang Pendidikan Tinggi seperti yang di jelaskan dalam pasal 11 dinyatakan bahwa : 1) Sivitas Akademika merupakan komunitas yang memiliki tradisi ilmiah dengan mengembangkan budaya akademik. 2) Budaya akademik sebagaimana dimaksud pada ayat (1) merupakan seluruh sistem nilai, gagasan, norma, tindakan, dan karya yang bersumber dari Ilmu Pengetahuan dan Teknologi sesuai dengan asas Pendidikan Tinggi. 3) Pengembangan budaya akademik sebagaimana dimaksud pada ayat (1) dilakukan dengan interaksi sosial tanpa membedakan suku, agama, ras, antargolongan, jenis kelamin, kedudukan sosial, tingkat kemampuan ekonomi, dan aliran politik. 4) Interaksi sosial sebagaimana dimaksud pada ayat (3) dilakukan dalam pembelajaran, pencarian kebenaran ilmiah, penguasaan dan/atau pengembangan Ilmu Pengetahuan dan Teknologi serta pengembangan Perguruan Tinggi sebagai lembaga ilmiah. 5) Sivitas Akademika berkewajiban memelihara dan mengembangkan budaya akademik dengan memperlakukan Ilmu Pengetahuan dan Teknologi sebagai proses dan produk serta sebagai amal dan paradigma moral. ${ }^{2}$

\footnotetext{
${ }^{1}$ Koentjaraningrat, Pengantar Antropologi, (Jakarta: Rineka Cipta, 2001). 72.

2 Undang-Undang nomor 12 tahun 2012, tentang Pendidikan Tinggi. 4
} 
Tantangan faktor internal menunjuk pada adanya perubahan sumberdaya manusia hasil didikan Perguruan Tinggi yang semata-mata tidak hanya berdasarkan pada persyaratan penguasaan ilmu dan ketrampilan, tetapi juga pada persyaratan sikap dan semangat belajar, pengenalan bidang lapangan pekerjaan dan kepercayaan masyarakat terhadap pendidikannya serta adanya semangat otonomi sesuai dengan UU No.32 tahun 2004. Sedangkan tantangan yang bersifat eksternal menunjuk pada adanya persaingan tenaga kerja yang menglobal, tuntutan pendidikan tinggi yang humanis, internasionalisasi pendidikan yang bersifat lintas negara yang dalam era globalisasi disebut dengan istilah 'etnoscapes'. ${ }^{3}$

Guna mencapai tujuan pendidikan, salah satu fator penting dalam penyelenggaraan pendidikan tinggi harus didukung oleh sistem organisasi pendidikan yang baik, sarana dan prasarana yang memadai (kualiatas SDM dan fasilitas yang dibutuhkan untuk mendukung proses belajar dan mengajar), juga dipengaruhi oleh fator kurikulum yang tepat. Kehidupan dan kegiatan akademik diharapkan selalu berkembang, bergerak maju bersama dinamika perubahan dan pembaharuan sesuai tuntutan zaman. Perubahan dan pembaharuan dalam kehidupan dan kegiatan akademik menuju kondisi yang ideal senantiasa menjadi harapan dan dambaan setiap insan yang mengabdikan dan mengaktualisasikan diri melalui dunia pendidikan tinggi dan penelitian, terutama mereka yang menggenggam idealisme dan gagasan tentang kemajuan. Perubahan dan pembaharuan ini hanya dapat terjadi apabila digerakkan dan didukung oleh pihakpihak yang saling terkait, memiliki komitmen dan rasa tanggungjawab yang tinggi terhadap perkembangan dan kemajuan budaya akademik.

Masalah budaya akademik yang cenderung sulit berkembang di perguruan tinggi Indonesia, telah menjadi topik perbincangan. Beberapa pakar pendidikan meyakini bahwa kemunduran kultur akademik bukan hanya karena pengaruh birokrasi pendidikan tetapi juga akibat keadaan internal perguruan tinggi itu sendiri. Di antaranya yang menjadi bahan polemik adalah masalah mataramisme yang mendarah daging dalam interaksi sosiologis di setiap perguruan tinggi. Perguruan tinggi sebagai suatu institusi dalam masyarakat memiliki ciri khas tersendiri di samping lapisan-lapisan masyarakat lainnya. Warga dari suatu perguruan tinggi adalah insan-insan yang memiliki wawasan dan integritas ilmiah. Oleh karena itu masyarakat akademik harus senantiasa mengembangkan budaya ilmiah yang merupakan esensi pokok dari aktivitas perguruan tinggi seperti 1). Penghargaan terhadap pendapat orang lain secara obyektif; 2) Pemikiran rasional

\footnotetext{
${ }^{3}$ Istilah etnoscapes, dalam Arjun Appadurai, Pemisahan dan Perbedaan dalam Ekonomi Budaya Global". Modernitas pada Luas: Dimensi Budaya Globalisas, 1996. 167 menjelaskan bahwa maksud etnoscapes yaitu memperluas lanskap orang-orang yang membentuk dunia yang berubah di mana kita tinggal, yaitu turis, imigran, pengungsi, atau kelompok bergerak dan individu yang memiliki fitur mendasar dunia dan tampaknya memengaruhi politik (dan antara) negara sampai tingkat yang belum pernah terjadi sebelumnya Appadurai mengklaim bahwa ini bukan untuk mengatakan tidak ada komunitas dan jaringan kekerabatan, persahabatan, pekerjaan, dan waktu luang yang relatif stabil, serta kelahiran, tempat tinggal, dan bentuk berbakti lainnya. Tetapi dapat dikatakan bahwa lengkungan kestabilan ini di mana-mana ditembakkan dengan gerakan manusia, karena semakin banyak orang dan kelompok yang berurusan dengan kenyataan harus berpindah dari fantasi ingin pindah. Ethnoscapes memungkinkan untuk mengenali bahwa gagasan tentang ruang, tempat dan komunitas telah menjadi jauh lebih kompleks, bahkan sebuah 'komunitas tunggal' sekarang dapat tersebar di berbagai situs.
} 
dan kritis-analitis dengan tanggungjawab moral; 3) Kebiasaan membaca; 4) Penambahan ilmu dan wawasan; 5) Kebiasaan meneliti dan mengabdi kepada masyarakat; 6) Penulisan artikel, makalah, buku; 7) Diskusi ilmiah; 8) Proses belajar-mengajar, dan 9) Manajemen perguruan tinggi yang baik.

Fakultas Ilmu Tarbiyah dan Keguruan adalah Fakultas tertua yang menjadi standar pengembangan dari fakultas-fakultas yang ada di IAIN Sultan Amai Gorontalo. Sejak tahun 1975 berstatus filial dari IAIN Alauddin Ujung pandang, selanjutnya tahun 1987 berubah Status menjadi Fakultas Madya IAIN Alauddin Makasar di Gorontalo dan pada tahun 1994 berubah menjadi Sekolah Tinggi Agama Islam Negeri (STAIN), dimana Tarbiyah menjadi Jurusan yang memiliki Program Studi S1 Pendidikan Islam, Program studi (PAI) program studi S1 Kependidikan Islam (KI), dan Diploma Dua Pendidikan Agama Islam (D2-PAI). Di tahun 2004 STAIN Sultan Amai Gorontalo setelah berubah status menjadi Institut Agama Islam Negeri (IAIN) Sultan Amai maka Tarbiyah terlah menjadi Fakultas serta memiliki 6 (enam) program studi masing-masing S1 Pendidikan Agama Islam, S2 Menejemen Pendidikan Islam, S1 Pendidikan Guru Madrasah Ibtidaiyah, S1 Pendidikan Guru Raudlatul Atfal, S1 Pendidikan Bahasa Arab dan S1 Pendidikan Bahasa Inggris.

Sesuai dengan pengamatan awal penulis program pengembangan budaya akademik pada program studi di Fakultas Ilmu Tarbiyah dan Keguruan IAIN Sultan Amai Gorontalo seperti yang dipersyaratkan dalam dalam ayat 2, 4 dan 5 pasal 11 UUPT nomor 12 tahun 2012 belum sepenuhnya dilaksanakan bahkan dari sisi nilai akademik yang seharusnya dalam visi program studi menyatakan bahwa setiap mahasiswa harus memiliki tatanan nilai spiritual dan menguasai serta mengamalkan kedalam kajian ilmu agama, tetapi kenyataannya berdasarkan pengamatan penulis masih banyak mahasiswa yang belum lancar membaca ayatayat al Quran, melaksanakan ibadah shalat 5 waktu di masjid kampus, Demikian pula dengan dosen yang mengajar masih banyak yang belum menggunakan media laboratorium mikro teaching dan laboratorium bahasa dan studio sebagai bentuk tindak lanjut pengembangan disiplin ilmu yang diajarkan. Demikian pula dalam budaya pengembangan intelektual dosen masih kurang dalam menulis, membuat buku, membuat bahan ajar, menulis di jurnal yang bisa di terbitkan dan dipublikasikan di tingkat nasional maupun internasional, bahkan terdapat dosen mengajarkan mata kuliah tidak sesuai dengan kompetensinya, Dalam hal pengabdian masyarakat tidak ditemukan dosen yang melakukan pengabdian masyarakat secara berjenjang dan berkesinambungan, dan dari 74 dosen (ASN dan Non ASN) FITK IAIN Sultan Amai Gorontalo, terdapat 45 dosen (60.81 \%) belum memiliki ijazah S3 (Doktor) dan belum ada pula yang Dosen yang berstatus Guru Besar.

\section{Metode Penelitian}

Penelitian ini dilaksanakan di Fakultas Ilmu Tarbiyah dan Keguruan IAIN Sultan Amai Gorontalo. Fakultas ini adalah fakultas yang tertua sejak IAIN Sultan Amai berdiri yang memiliki PAI, MPI, Pendidikan Bahasa Arab, Tadris Bahasa Inggris, Pendidikan Guru Madrasah Ibtidaiyah dan Pendidikan Islam Anak Usia Dini. Sedangkan jenis penelitian ini menggunakan gabungan metode kualitatif dan 
kuantitatif yang disebut mixed methods (metode campuran/kombinasi). ${ }^{4}$ Data kualitatif dan kuantitatif dikumpulkan untuk saling melengkapi. ${ }^{5}$ Penelitian kuantitatif dengan teknik kuesioner, dan untuk mengetahui atau mengecek kebenaran data dilakukan dengan teknik observasi, wawancara dan dokumentasi. ${ }^{6}$

Teknik pengumpulan data yang digunakan dalam penelitian ini pertama, Observasi yaitu Pengumpulan data dengan cara pengamatan langsung dengan tanpa menggunakan alat bantu Dalam hal ini pengamatan yang dilakukan, dapat berupa pengamatan yang terstruktur maupun tak terstruktur (eksploratori). Sedangkan berkaitan dengan posisi peneliti dalam hubungannya dengan subyek penelitian (sumber data), dipilih teknik pengamatan terlibat. Peneliti bersosialisasi di lingkungan sebagai bagian integral dari lingkungan, Dengan demikian diharapkan berbagai informasi akan terungkap, dan mudah didapatnya, demikian pula keakuratan data lebih terjamin. Meskipun seorang peneliti di sini harus melepas semua subyektifitas yang dimilikinya dimaksud. ${ }^{7}$

Kedua, Inteview. Teknik ini akan memberikan informasi unik dengan struktur bahasa yang unik pula. Dalam penggunaan teknik ini, maka susunan kalimat dari narasumber dibiarkan apa adanya, untuk memberikan aksentuasi pada jawaban responden sebagaimana adanya. Jenis wawancara yang digunakan adalah wawancara tidak terstruktur, yaitu wawancara yang penelitinya hanya membuat garis besar arah pembicaraan, agar memungkinkan penggalian informasi yang lebih mendalam dan detail, serta menunjang posisioning peneliti sebagai teman. Variasi yang mungkin dilakukan hanyalah bentuk wawancara semi struktur, yaitu dengan pengajuan serentetan pertanyaan dasar yang sudah terstruktur sederhana di awal, dengan dilanjutkan pendalaman yang secara murni tidak terstruktur. ${ }^{8}$ Ketiga, Dokumentasi. yaitu peneliti mencari sumber-sumber data berupa catatan, buku maupun dokumen yang berhubungan dengan obyek penelitian.

Sedangkan teknik analisis data meliputi: pertama, Reduksi data Merupakan proses pemilihan, pemutusan perhatian pada penyederhanaan dan transformasi data kasar yang muncul dari catatan-catatan lapangan. Reduksi data berlangsung terus-menerus selama penelitian berlangsung. ${ }^{9}$

Kedua, Display Adalah proses pengumpulan data sehingga memudahkan dalam menganalisa. Beberapa data yang ada disusun dalam satuan dan diberikan kode sesuai dengan tema. ${ }^{10}$

Ketiga, Kritik Adalah proses penelitian secara mendalam dan hati-hati terhadap obyek penelitian data, karena tidak menutup kemungkinan akan terjadinya perkembangan dan ditemukannya hal-hal yang baru. ${ }^{11}$

Keempat Pengambilan kesimpulan dan verifikasi merupakan langkah akhir dari analisa data, setelah langkah ini selesai peneliti mulai mengolah data. Dalam

\footnotetext{
${ }^{4}$ Sugiyono, Metode Penelitian Kombinasi (Mixed Methods), (Bandung, Alfabeta, 2014). 404

5 Ibid. 401

${ }^{6}$ Ibid. 400

${ }^{7}$ Setya Y. Sudikan, Metode Penelitian Pendidikan (Surabaya: UNESA Unipress, 2001), 175.

8 Sanapiah Faisal, Metode Penelitian Pendidikan (Surabaya: Usaha Nasional, 1982), 215.

${ }^{9}$ Imam Suprayogo dan Tobroni, Metodologi Penelitian Sosial Agama (Bandung: Remaja Rosdakarya, 2001), 192-193.

${ }^{10}$ Lexy J Moleong, Metodologi Penelitian Kualitatif (Bandung: Remaja Rosda Karya, 2002), 190.

11 Noeng Muhajir, Filsafat Ilmu, (Yogyakarta: Rake Sarasin, 2001), 109.
} 
analisis, kegiatan pengumpulan data, reduksi data, penyajian dan penarikan kesimpulan merupakan proses siklus yang berlangsung terus menerus. Selain itu juga dilakukan analisis perbandingan atas pertimbangan kondisi harapan dan kenyataan, sehingga dikatahui tingkat penyimpangan data dari pola idealitasnya. ${ }^{12}$

\section{Pembahasan dan Hasil Penelitian Pengertian Budaya Akademik}

Sutan Takdir Alisyahbana mendefinisikan bahwa budaya adalah manifestasi dari cara berpikir, sehingga pola kebudayaan itu sangat luas karena semua laku dan perbuatan tercakup di dalamnya dan dapat diungkapkan pada basis dan cara berpikir, termasuk di dalamnya perasaan karena perasaan juga merupakan maksud dari pikiran. ${ }^{13}$ Supartono Widyosiswoyo mendefinisikan kata budaya secara bahasa berasal dari kata budh dalam bahasa Sanskerta yang berarti akal, kemudian menjadi kata budhi (tunggal) dan budhaya (jamak dari budhi), sehingga budaya diartikan sebagai "hasil pemikiran manusia". Menurutnya pula, ada pendapat yang mengatakan bahwa kebudayaan berasal dari kata budi dan daya. Budi adalah akal yang merupakan unsur rohani dalam kebudayaan, sedangkan daya berarti perbuatan atau ikhtiar sebagai unsur jasmani, sehingga "kebudayaan diartikan sebagai hasil dari akal dan ikhtiar manusia".14

Budaya menurut Edward Taylor "Culture or civilization complex whole which includes knowledges, belief, art, morals, law, custom, and any other capabilities and habits acquired by man as a member of society (kultur atau peradaban kompleksitas menyeluruh yang terdiri dari pengetahuan, keyakinan, seni, moral, hukum, adat kebiasaan dan berbagai kapabilitas lainnya serta kebiasaan apa saja yang diperoleh seorang manusia sebagai bagian dari sebuah masyarakat)". 15 Malinowski menyatakan "Culture obviously is the integral whole consisting of implement and consumer's goods, the constitutional charters for various social grouping, of human ideas and crafts, beliefs and customs" (kultur adalah keseluruhan kehidupan manusia yang integral yang terdiri dari berbagai peralatan dan barang-barang konsumen, berbagai peraturan untuk kehidupan masyarakat, ide-ide dan hasil karya manusia, keyakinan dan kebiasaan masyarakat). ${ }^{16}$

Beberapa pengertian budaya di atas, merupakan suatu cara hidup yang berkembang dan dimiliki bersama oleh sekelompok orang dan diwariskan dari generasi ke generasi. Budaya bersifat kompleks, abstrak dan luas yang terdiri dari pengetahuan, keyakinan, seni, moral, hukum, adat kebiasaan dan berbagai kapabilitas lainnya serta kebiasaan apa saja yang diperoleh seorang manusia sebagai bagian dari sebuah masyarakat. Kata Akademik secara etimologi berasal dari bahasa Yunani yaitu academos yang berarti sebuah "taman umum (plasa)" di sebelah barat laut kota Athena. ${ }^{17}$ Pengertian akademik secara terminologi adalah

\footnotetext{
12 Suharsimi Arikunto, Prosedur Penelitian, 257-258.

${ }^{13}$ Supartono Widyosiswoyo, Ilmu Budaya Dasar, (Bogor: Ghalia Indonesia, 2009). 31.

14 Supartono Widyosiswoyo, Ilmu Budaya Dasar. 30

15 A. Sobirin, Budaya Organisasi, (Yogyakarta: UPP STIM YKPN, 2009). 50.

${ }^{16}$ A. Sobirin, Budaya Organisasi. 50

${ }^{17}$ M. Fajar, Mahasiswa dan Budaya Akademik (Bandung: Rineka Cipta, 2002). 56.
} 
keadaan orang-orang bisa menyampaikan dan menerima gagasan, pemikiran, ilmu pengetahuan, dan sekaligus dapat mengujinya secara jujur, terbuka, dan leluasa. ${ }^{18}$

Dengan demikian, budaya akademik (Academic Culture) dapat dipahami sebagai suatu totalitas dari kehidupan dan kegiatan akademik yang dihayati, dimaknai dan diamalkan oleh warga masyarakat akademik di suatu lembaga pendidikan. Akhmad Minhaji mengemukakan bahwa banyak kata dan istilah yang bisa menggambarkan budaya akademik, antara lain academic tradition (tradisi akademik), academic culture (budaya akademik), academic atmosphere (suasana akademik), academic standing (kedudukan akademik), academic freedom (kebebasan akademik), scholarly activities (aktivitas kesarjanaan), dan yang semacamnya. ${ }^{19}$

Perguruan Tinggi sebagai suatu organisasi, memiliki budaya tersendiri yang dibentuk dan dipengaruhi oleh nilai-nilai, persepsi, kebiasaan-kebiasaan, kebijakankebijakan pendidikan, dan perilaku orang-orang yang berada di dalamnya. Budaya Akademik dapat dipahami sebagai suatu totalitas dari kehidupan dan kegiatan akademik yang dihayati, dimaknai dan diamalkan oleh warga masyarakat akademik, di lembaga pendidikan tinggi dan lembaga penelitian. Membangun budaya akademik bukan perkara yang mudah. Diperlukan upaya sosialisasi terhadap kegiatan akademik, sehingga terjadi kebiasaan di kalangan akademisi untuk melakukan norma-norma kegiatan akademik tersebut.

Budaya akademik sebagai suatu subsistem perguruan tinggi memegang peranan penting dalam upaya membangun dan mengembangkan kebudayaan dan peradaban masyarakat (civilized society) dan bangsa secara keseluruhan. Indikator kualitas Perguruan Tinggi sekarang dan terlebih lagi pada milenium ketiga ini akan ditentukan oleh kualitas civitas akademika dalam mengembangkan dan membangun budaya akademik ini. ${ }^{20}$ Budaya Akademik adalah "Budaya atau sikap hidup yang selalu mencari kebenaran ilmiah melalui kegiatan akademik dalam masyarakat akademik, yang mengembangkan kebebasan berpikir, keterbukaan, pikiran kritis-analitis; rasional dan obyektif oleh warga masyarakat akademik" Konsep dan pengertian tentang Budaya Akademik tersebut didukung perumusan karakteristik perkembangannya yang disebut "Ciri-Ciri Perkembangan Budaya Akademik."

Tradisi Akademik adalah "Tradisi yang menjadi ciri khas kehidupan masyarakat akademik dengan menjalankan proses belajar-mengajar antara dosen dan mahasiswa; menyelenggarakan penelitian dan pengabdian kepada masyarakat, serta mengembangkan cara-cara berpikir kritis-analitis, rasional dan inovatif di lingkungan akademik." 21 Pengertian tentang "Kebebasan Akademik" adalah Kebebasan yang dimiliki oleh pribadi-pribadi anggota sivitas akademika (mahasiswa dan dosen) untuk bertanggungjawab dan mandiri yang berkaitan dengan upaya penguasaan dan pengembangan Iptek dan seni yang mendukung

\footnotetext{
18 Imam Barnadib, Kode Etik Akademik: Telaah Deskriptif Awal, (Yogyakarta: Taman Siswa, 2002). 14.

${ }^{19}$ Akhmad Minhaji, Tradisi Akademik di Perguruan Tinggi, (Yogyakarta: SUKA Press, 2013). 8.

${ }^{20}$ Rides Alfoart, Budan dan Mimbar Akademik : http://blogkita.info/budaya-akademik-2/ diakses pada 25 Januari 2019

${ }^{21}$ Kaelan, M,S. Pendidikan Pancasila. Edisi 8. (Yogyakarta: Paradigma, 2004).43.
} 
pembangunan nasional. Kebebasan akademik meliputi kebebasan menulis, meneliti, menghasilkan karya keilmuan, menyampaikan pendapat, pikiran, gagasan sesuai dengan bidang ilmu yang ditekuni, dalam kerangka akademis. ${ }^{22}$

Mahasiswa adalah sosok yang semestinya kritis, logis, berkemauan tinggi, respectdan tanggap terhadap permasalahan umat dan bangsa, mau bekerja keras, belajar terus menerus, mempunyai nyali (keberanian yang tinggi) untuk menyatakan kebenaran, aplikatif di lingkungan masyarakat serta spiritualis dan konsisten dalam mengaktualisasikan nilai-nilaiketauhidan kepada Tuhan Yang Maha Esa. Dengan Konsep itulah, mahasiswa semestinya bergerak dan menyadari dirinya akan eksistensi ke-mahahasiswaan nya itu. Belajar tidaklah hanya sebatas mengejar gelar akademis atau nilai indeks prestasi ( IP ) yang tinggi dan mendapat penghargaan cumlaude, lebih dari itu mahasiswa harus bergerak bersama rakyat dan pemerintah untuk membangun bangsa, atau paling tidak dalam lingkup yang paling mikro, ada suatu kemauan untuk mengembangkan civitas/ perguruan tinggi dimana ia kuliah. Misalnya dengan ikut serta/ aktif di Organisasi Mahasiswa, baik itu Organisasi intra kampus ( BEM dan UKM) ataupun Organisasi Ekstra kampus, serta aktif dalam kegiatan-kegiatan lain yang mengarah pada pembangunan bangsa. Budaya akademik dapat dikatagorikan sebagai cara hidup masyarakat ilmiah yang majemuk, multikultural yang bernaung dalam sebuah institusi yang mendasarkan diri pada nilai-nilai kebenaran ilmiah dan objektifitas. Budaya Akademik (Academic Culture) dapat dipahami sebagai suatu totalitas dari kehidupan dan kegiatan akademik yang dihayati, dimaknai dan diamalkan oleh warga masyarakat akademik, di lembaga pendidikan tinggi dan lembaga penelitian. ${ }^{23}$

Kehidupan dan kegiatan akademik diharapkan selalu berkembang, bergerak maju bersama dinamika perubahan dan pembaharuan sesuai tuntutan zaman. Perubahan dan pembaharuan dalam kehidupan dan kegiatan akademik menuju kondisi yang ideal senantiasa menjadi harapan dan dambaan setiap insan yang mengabdikan dan mengaktualisasikan diri melalui dunia pendidikan tinggi dan penelitian, terutama mereka yang menggenggam idealisme dan gagasan tentang kemajuan. Perubahan dan pembaharuan ini hanya dapat terjadi apabila digerakkan dan didukung oleh pihak-pihak yang saling terkait, memiliki komitmen dan rasa tanggung-jawab yang tinggi terhadap perkembangan dan kemajuan budaya akademik.

Budaya akademik sebenarnya adalah budaya universal. Artinya, dimiliki oleh setiap orang yang melibatkan dirinya dalam aktivitas akademik. Membangun budaya akademik bukan perkara yang mudah. Diperlukan upaya sosialisasi terhadap kegiatan akademik, sehingga terjadi kebiasaan di kalangan akademisi untuk melakukan norma-norma kegiatan akademik tersebut. Pemilikan budaya akademik ini seharusnya menjadi idola semua insan akademisi perguruaan tinggi, yakni dosen dan mahasiswa. Derajat akademik tertinggi bagi seorang dosen adalah dicapainya kemampuan akademik pada tingkat guru besar (profesor). Sedangkan

\footnotetext{
${ }^{22}$ Keputusan Menteri Pendidikan dan Kebudayaan Republik Indonesia No. 056/U/1994 tentang Pedoman Penyusunan Kurikulum Pendidikan Tinggi dan Penilaian Belajar Mahasiswa

${ }^{23}$ Keputusan Menteri Pendidikan Nasional Republik Indonesia No. 232/U/2000 tentang Pedoman Penyusunan Kurikulum Pendidikan Tinggi dan Penilaian Belajar Mahasiswa
} 
bagi mahasiswa adalah apabila ia mampu mencapai prestasi akademik yang setinggi-tingginya. ${ }^{24}$

Khusus bagi mahasiswa, faktor-faktor yang dapat menghasilkan prestasi akademik tersebut ialah terprogramnya kegiatan belajar, kiat untuk berburu referensi aktual dan mutakhir, diskusi substansial akademik, dan sebagainya. Dengan melakukan aktivitas seperti itu diharapkan dapat dikembangkan budaya mutu (quality culture) yang secara bertahap dapat menjadi kebiasaan dalam perilaku tenaga akademik dan mahasiswa dalam proses pendidikan di perguruaan tinggi. Oleh karena itu, tanpa melakukan kegiatan-kegiatan akademik, mustahil seorang akademisi akan memperoleh nilai-nilai normative akademik. Bisa saja seorang akademisi mampu berbicara tentang norma dan nilai-nilai akademik tersebut didepan forum namun tanpa proses belajar dan latihan, norma-norma tersebut tidak akan pernah terwujud dalam praktik kehidupan sehari-hari. Bahkan sebaliknya, seorang akademisi tidak segan-segan melakukan pelanggaran dalam wilayah tertentu, baik disadari ataupun tidak.

Kiranya, dengan mudah disadari bahwa perguruan tinggi berperan dalam mewujudkan upaya dan pencapaian budaya akademik tersebut. Perguruan tinggi merupakan wadah pembinaan intelektualitas dan moralitas yang mendasari kemampuan penguasaan IPTEK dan budaya dalam pengertian luas disamping dirinya sendirilah yang berperan untuk perubahan tersebut. Perguruan tinggi merupakan suatu lingkungan pendidikan tinggi bukan merupakan lingkungan yang eksklusif. Dengan demikian, maka kampus merupakan komunitas atau masyarakat yang tersendiri yang disebut masyarakat akademik (academic community). Di dalam kampus terdapat kegiatan-kegiatan dan tata aturan yang lain dari yang lain. Oleh karena itu, kampus menjadi semacam lembaga akademik dan jalinan antar kampus memiliki suasana yang khas, yaitu suasana akademik (academic atmosphere). Ciriciri masyarakat akademik yaitu kritis, objektif, analitis, kreatif dan konstruktif, terbuka untuk menerima kritik, menghargai waktu dan prestasi ilmiah, bebas dari prasangka, kemitraan dialogis, memiliki dan menjunjung tinggi norma dan susila adademik serta tradisi ilmiah, dinamis, dan berorientasi kemasa depan.

Hak milik yang paling berharga bagi suatu perguruan tinggi adalah kebebasan, otonomi, dan budaya akademik (academic culture). Budaya akademik dapat dipahami sebagai suatu totalitas dari kehidupan dan kegiatan akademik yang dihayati, dimaknai dan diamalkan oleh warga masyarakat akademik khususnya di lembaga pendidikan. Budaya akademik lebih cenderung diarahkan pada budaya kampus (campus culture) yang tidak hanya bertujuan untuk meningkatkan intelektual, tetapi juga kejujuran, kebenaran dan pengabdian kepada kemanusiaan, sehingga secara keseluruhan budaya kampus adalah budaya dengan nilai-nilai karakter positif. ${ }^{25}$

Nilai-nilai utama karakter inilah yang sebenarnya menjadi penyokong utama dalam proses terciptanya budaya akademik. Budaya akademik sendiri adalah budaya universal yang seharusnya dimiliki oleh setiap orang yang melibatkan

24 Deddy Mulyana dan Jalaluddin Rakhmat. Komunikasi Antarbudaya: Panduan berkomunikasi dengan Orang-Orang Berbeda Budaya. (Bandung: Remaja Rosdakarya, 2006).223.

25 Malik Fajar, Budaya Akademik Perguruan Tinggi, http://maknaartikel.blogspot.com/ 2010/01/budaya-akademik/ survei.html. diakses 25 Januari 2019 
dirinya dalam aktivitas akademik. Budaya ini seharusnya melekat dalam diri semua insan akademisi perguruaan tinggi, baik itu dosen ataupun mahasiswa. Karena, pada dasarnya budaya akademik juga merujuk pada cara hidup masyarakat ilmiah yang majemuk dan multikultural yang bernaung dalam sebuah institusi yang mendasarkan diri pada nilai-nilai kebenaran ilmiah dan objektifitas. Perbincangan mengenai budaya akademik akan membawa kita pada sebuah kata kunci yang menjadi dasar pijakan untuk pembahasan selanjutnya, yaitu etika atau etik. Istilah Etika berasal dari bahasa Yunani, "ethos" yang artinya cara berpikir, kebiasaan, adat, perasaan, sikap, karakter, watak kesusilaan atau adat.

Dalam Kamus Bahasa Indonesia, ada 3 (tiga) arti yang dapat dipakai untuk kata Etika, salah satunya adalah etika sebagai sistem nilai atau sebagai nilai-nilai atau norma-norma moral yang menjadi pedoman bagi seseorang atau kelompok untuk bersikap dan bertindak. Etika juga bisa diartikan sebagai kumpulan azas atau nilai yang berkenaan dengan akhlak atau moral. Selain itu, Etika bisa juga diartikan sebagai ilmu tentang yang baik dan yang buruk yang diterima dalam suatu masyarakat, menjadi bahan refleksi yang diteliti secara sistematis dan metodis. ${ }^{26}$

Kata-kata etika, etik dan moral merujuk ke persoalan baik-buruk, lurusbengkok, benar-salah dan adanya penyimpangan ataupun pelanggaran praktek tidak lagi disebabkan oleh faktor yang bersifat di luar kendali manusia (force majeur), tetapi lebih diakibatkan oleh semakin kurangnya pemahaman etika yang melandasi perilaku manusia. Sementara itu banyak orang yang menaruh harapan terhadap lembaga pendidikan agar tidak hanya memberi bekal pengetahuan (knowledge) ataupun keterampilan (skill) saja kepada anak didik, melainkan juga pemahaman dan pembentukan soft skill seperti watak, sikap dan perilaku (attitude) di dalam kehidupan sehari-hari. Tiga aspek tersebut akhirnya akan menjadi dasar pembentukan dan penilaian terhadap kompetensi seseorang sebagai hasil dari sebuah proses pendidikan. Istilah etik merupakan istilah-istilah yang memiliki makna yaitu sebuah pengertian tentang salah dan benar, atau buruk dan baik. Pernyataan ini harus dipahami sebagai nilai-nilai tradisional yang meskipun terkesan konservatif karena mengandung unsur nilai kejujuran (honesty), integritas dan perhatian pada hak serta kebutuhan orang lain, tetapi sangat tepat dijadikan "standar" dalam menilai dan mempertimbangkan persoalan etika akademik, yang intinya menjunjung tinggi kebenaran ilmiah. ${ }^{27}$

Dalam konteks seni pergaulan manusia, etika ini kemudian diwujudkan dalam bentuk kode etik tertulis, yang secara sistematik dibuat berdasarkan prinsipprinsip moral yang ada, sehingga pada saat yang dibutuhkan dapat difungsikan sebagai dasar untuk menentukan segala macam tindakan yang secara logikarasional umum (common sense) dinilai menyimpang dari aturan, tata-tertib dan/atau kode etik yang mengaturnya. Dengan demikian, etika akademik dapat diartikan sebagai ketentuan yang menyatakan perilaku baik atau buruk dari para anggota civitas akademika perguruan tinggi, ketika mereka berbuat atau berinteraksi dalam kegiatan yang berkaitan dengan ranah dalam proses

${ }^{26}$ Departemen Pendidikan Nasional, Kamus Besar Bahasa Indonesia, (Jakarta: Balai Pustaka, 2000). 897.

${ }^{27}$ Another Lost Stories : Pre-Launching : Xiao Yi M1.ttp.03/ Kamera Mirrorless Versi Murah Mirip Leicahttp://blogkita.info/budaya-akademik-2/ /30 diakses 25 Januari 2019. 
pembelajaran. Achmad Minhaji, menegaskan bahwa tradisi akademik menyangkut banyak hal, tetapi dalam bahasa yang relatif lebih sederhana dapat dikatakan bahwa budaya akademik bisa dimaknai dengan dua cara, sebagai berikut: Pertama, tradisi akademik adalah menyangkut input-processoutput, dan semuanya bertumpu pada makna pedagogik yang sebenarnya, baik pedagogik tradisional, pedagogik kritis, maupun pedagogik transformatif. Pedagogik tradisional yakni pendidikan yang berpusat pada proses pembelajaran peserta didik. Pedagogik kritis yakni penggunaan pendekatan sosio politik dan bertujuan memberdayakan peserta didik agar sadar keberadaannya dalam konteks sosial politik, budaya dan ekonomi masyarakat. Sedangkan pedagogik transformatif, yakni berfokus pada individu yang partisipatif dalam perubahan sosial dengan tujuan menyadarkan dan mengembangkan potensi individu dalam kehidupan masyarakat. Makna kedua budaya akademik adalah suatu aktivitas yang diabdikan untuk (1) usaha mengembangkan pengetahuan baru secara terus-menerus (the continuous search for new knowledge), (2) usaha mencari kebenaran yang dilakukan secara terus menerus (the continuous search for truth), dan (3) usaha menjaga khazanah pengetahuan yang telah ada dari berbagai jenis pemalsuan (the continuous defense of the body knowledge against falsification). ${ }^{28}$ Pengertian budaya akademik tersebut di atas lebih relevan dengan kehidupan akademik di tingkat Perguruan Tinggi. Karena kedua makna budaya akademik tersebut identik dengan Tridharma Perguruan Tinggi, yaitu melaksanakan pendidikan dan pengajaran, penelitian, dan pengabdian kepada masyarakat.

\section{Indikator Budaya Akademik}

Derajat akademik tertinggi bagi seorang dosen adalah dicapainya kemampuan akademik pada tingkat guru besar (profesor). Sedangkan bagi mahasiswa adalah apabila ia mampu mencapai prestasi akademik yang setinggi-tingginya. Khusus bagi mahasiswa, faktor-faktor yang dapat menghasilkan prestasi akademik tersebut ialah terprogramnya kegiatan belajar, kiat untuk berburu referensi aktual dan mutakhir, diskusi substansial akademik, dan sebagainya. Kualifikasi komponen budaya akademik meliputi :1) Pengembangan Sumber Daya Manusia masyarakat akademik, 2) Pengembangan infrastruktur pendidikan, 3) Pengembangan kinerja civitas akademika, 4) Peningkatan kualitas pembelajaran, 5) Tersedia jaminan mutu, 6) Tersedia perpustakaan yang berkualitas, 7) Tersedia ICT yang sangat berkualitas, 8) Tersedia Laboratorium yang berbasis kebutuhan, 9) Terselenggara forum diskusi, seminar dan workshop, 10) Dihasilkan karya tulis ilmiah melalui jurnal, koran, majalah dan buku. ${ }^{29}$

Mulyadi menyatakan bahwa secara teoritis untuk melihat budaya akademikik dapat digunakan dua indikator pokok, yaitu fleksibilitas dan fokus. Fleksibilitas dapat dilihat dari dua titik ekstrim, yaitu fleksibel dan statis (stabil). Fokus dapat

\footnotetext{
${ }^{28}$ Achmad Minhaji, Tradisi Akademik di Perguruan Tinggi . 13-14 .

${ }^{29}$ Samudi, "Upaya Meningkatkan Budaya Akademik di Perguruan Tinggi", Materi disampaikan pada acara Seminar Ilmiah di lingkungan Perguruan Tinggi La Tansa Mashiro.ari Jum'at tanggal 23 Maret 2012 di Hall Perguruan Tinggi La Tansa Mashiro Rangkasbitung, http://samudimpd.blogspot.co.id/,, diakses 24-01-2020.
} 
dilihat dari dua sisi, yaitu fokus internal dan fokus eksternal. ${ }^{30}$ Bila fleksibel dan fokusnya adalah eksternal maka budaya yang berkembang adalah budaya adaptif. Noor Rahman dalam kutipan Mulyadi menyatakan bahwa budaya adaptif memiliki ciri-ciri kreatif, berani melakukan eksperimentasi, berani mengambil resiko, mandiri dan responsif. Apabila fleksibel tetapi fokusnya internal maka budayanya adalah kekeluargaan. Ciri-ciri budaya kekeluargaan adalah mengedepankan kerjasama, penuh pertimbangan, persetujuan bersama, kesetaraan dan keadilan. ${ }^{31}$

Apabila organisasinya cenderung stabil (tidak fleksibel) dan fokusnya eksternal maka budaya yang berkembang adalah budaya prestasi. Budaya prestasi memiliki ciri-ciri berorientasi pada persaingan atau kompetisi, mengumpulkan kesempurnaan, agresif, aktif dan rajin, mendorong munculnya inisiatif anggota. Namun demikian, kestabilan tersebut sangat tergantung pada banyak hal, sehingga harus berupaya untuk selalu menjadi yang terbaik, karena dengan menjadi yang terbaik akan lebih mudah untuk mengendalikan berbagai harapan dan kebutuhan stakeholders. ${ }^{32}$ Apabila organisasi cenderung stabil dan fokusnya internal maka budayanya adalah birokrasi. Budaya birokrasi ditandai adanya formalitas hubungan di dalam maupun dengan pihak luar, mementingkan efisiensi, menekankan rasionalitas, teratur dan berjenjang, menuntut adanya kepatuhan dari pihak-pihak di bawah pimpinan. ${ }^{33}$

\section{Membangun Budaya Akademik}

Dalam dunia pendidikan di Perguruan Tinggi mengistilahkan budaya organisasi dengan istilah kultur akademis yang pada intinya mengatur para pendidik agar mereka memahami bagaimana seharusnya bersikap terhadap profesinya, beradaptasi terhadap rekan kerja dan lingkungan kerjanya, serta berlaku reaktif terhadap kebijakan pimpinannya sehingga terbentuklah sebuah sistem nilai, kebiasaan (habits), citra akademis dan etos kerja yang terinternalisasikan dalam kehidupannya sehingga mendorong adanya apresiasi dirinya terhadap peningkatan prestasi kerja, baik terbentuk oleh lingkungan organisasi tersebut maupun dikuatkan secara organisatoris oleh pimpinan akademis yang mengeluarkan sebuah kebijakan yang diterima ketika seseorang masuk organisasi tersebut.

Kaelan menjelaskan bahwa budaya akademik yang perlu dibangun atau dikembangkan meliputi: 1) Sikap Kritis, yaitu setiap insan akademis harus senantiasa mengembangkan sikap ingin tahu segala sesuatu untuk selanjutnya diupayakan jawaban dan pemecahannya melalui suatu kegiatan ilmiah penelitian. 2) Kreatif, yaitu setiap insan akademis harus senantiasa mengembangkan sikap inovatif, berupaya untuk menemukan sesuatu yang baru dan bermanfaat bagi masyarakat. 3) Obyektif, yaitu kegiatan ilmiah yang dilakukan harus benar-benar berdasarkan pada suatu kebenaran ilmiah, bukan karena kekuasaan, uang atau

\footnotetext{
${ }^{30}$ Mulyadi, Kepemimpinan Kepala Madrasah Dalam Mengembangkan Budaya Mutu, (Jakarta: Badan Litbang dan Diklat Kemenag RI, 2010). 50-51.

31 Mulyadi, Kepemimpinan Kepala Madrasah Dalam Mengembangkan Budaya Mutu.51.

32 Muhaimin, et. al. Manajemen Pendidikan: Aplikasinya dalam Penyusunan Rencana Pengembangan Sekolah atau Madrasah, (Jakarta: Kencana, 2010). 57.

33 Mulyadi, Kepemimpinan Kepala Madrasah Dalam Mengembangkan Budaya Mutu.54
} 
ambisi pribadi. 4) Analitis, yaitu suatu kegiatan ilmiah harus dilakukan dengan suatu metode ilmiah yang merupakan suatu prasyarat untuk tercapainya suatu kebenaran ilmiah. 5) Konstruktif, yaitu suatu kegiatan ilmiah yang merupakan budaya akademik harus benar-benar mampu mewujudkan suatu karya baru yang memberikan asas kemanfaatan bagi masyarakat. 6) Dinamis, yang berarti ciri ilmiah sebagai budaya akademik harus dikembangkan terus-menerus, 7) Dialogis, artinya dalam proses transformasi ilmu pengetahuan dalam masyarakat akademik harus memberikan ruang pada semua masyarakat ilmiah untuk mengembangkan diri,melakukan kritik serta mendiskusikannya, 8) Menerima kritik, ciri ini sebagai suatu konsekuensi suasana dialogis yaitu setiap insan akademik senantiasa bersifat terbuka terhadap kritik, 9) Menghargai prestasi ilmiah/akademik, masyarakat intelektual akademik harus menghargai prestasi akademik, yaitu prestasi dari suatu kegiatan ilmiah, 10) Bebas dari prasangka, yang berarti budaya akademik harus mengembangkan moralitas ilmiah yaitu harus mendasarkan kebenaran pada suatu kebenaran ilmiah, 11) Menghargai waktu, yang berarti masyarakat intelektual harus senantiasa memanfaatkan waktu seefektif dan seefisien mungkin, terutama demi kegiatan ilmiah dan prestasi kerja, 12) Memiliki dan menjunjung tinggi tradisi ilmiah, yang berarti masyarakat akademik harus benar-benar memiliki karakter ilmiah sebagai inti pokok budaya akademik, 13) Berorientasi ke masa depan, artinya suatu masyarakat akademik harus mampu mengantisipasi suatu kegiatan ilmiah ke masa depan dengan suatu perhitungan yang cermat, realistis dan rasional, 14) Kesejawatan/kemitraan, artinya suatu masyarakat ilmiah harus memiliki rasa persaudaraan yang kuat untuk mewujudkan suatu kerja sama yang baik. Oleh karena itu budaya akademik senantiasa memegang dan menghargai tradisi almamater sebagai suatu tanggung jawab moral masyarakat intelektual akademik, 15) Kebebasan akademik meliputi kebebasan menulis, meneliti, menghasilkan karya keilmuan, menyampaikan pendapat, pikiran, gagasan sesuai dengan bidang ilmu yang ditekuni, dalam kerangka akademis. ${ }^{34}$

Dengan adanya budaya akademik tersebut dapat disimpulkan bahwa budaya warga akademik meliputi setiap insan yang berpikir kritis, kreatif, objektif, analitis, konstruktif, dinamis, dialogis, menerima kritik, menghargai prestasi akademik, bebas dari prasangka, menghargai waktu, menjunjung tradisi ilmiah, berorientasi ke masa depan, dan kemitraan. Adanya sikap dan perilaku masyarakat ilmiah di atas pada suatu lembaga pendidikan akan mendorong lahirnya budaya akademik yang baik di lembaga tersebut.

\section{Pengembangan Budaya Akademik Fakultas Ilmu Tarbiyah dan Keguruan IAIN Sultan Amai Gorontalo}

Budaya akademik (Academic culture), dapat dipahami sebagai suatu totalitas dari kehidupan dan kegiatan akademik yang dihayati, dimaknai dan diamalkan oleh warga akademik. Suatu cara hidup yang berkembang dan dimiliki warga akademik yang selalu mencari kebenaran ilmiah melalui kegiatan akademik, yang mengembangkan kebebasan berpikir, keterbukaan, pikiran kritis-analitis; rasional, obyektif, kreatif, analitis, konstruktif, dinamis, dialogis, menerima kritik, menghargai prestasi akademik, bebas dari prasangka, menghargai waktu,

34M. S. Kaelan, Pendidikan Pancasila, (Yogyakarta: Paradigma, 2004). 73 
menjunjung tradisi ilmiah, berorientasi ke masa depan, dan kemitraan. Hasil penelitian diperoleh bahwa budaya akademik berdasarkan Tri dharma Peguruan tinggi yang terdiri dari pendidikan, penelitian dan pengabdian kepada masyarakat.

\section{Pendidikan dan Pengajaran}

Fakta yang ada di lapangan, budaya akademik dibidang pendidikan antara lain: 1) kerjasama team teaching antar dosen, dosen dengan mahasiswa dan antar mahasiswa; 2) proses perkuliahan yang terprogram dan terjadwal; 3) budaya membaca dan menghafal; 4) beda buku; dan 5) Workshop/lokakarya/Seminar/ Simposiun/Diskusi Panel. Berdasarkan hasil penelitian melalui kuesioner dengan mengambil sampel 35 orang responden bahwa budaya akademik bidang pendidikan sebagai berikut:

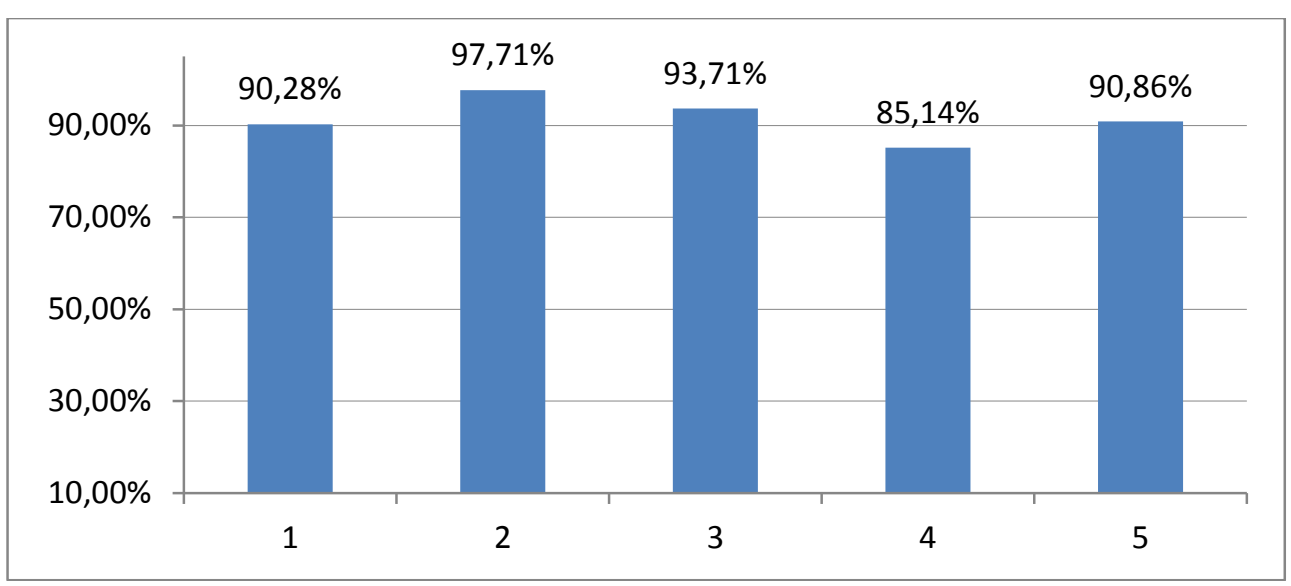

Diagram Budaya Akademik bidang Pendidikan

Keterangan:

1. Kerjasama team teaching $90.28 \%$

2. Proses perkuliahan/pembelajaran $97.71 \%$

3. Budaya membaca dan menghafal $93.71 \%$

4. Beda buku $85.14 \%$

5. Workshop/lokakarya/Seminar/ Simposiun/Diskusi Panel $90.86 \%$

Dari kelima budaya akademik tersebut di atas dapat dilihat bahwa bidang pendidikan rata-rata mencapai $91.54 \%$. Hal ini menunjukkan bahwa budaya pendidikan berkembang dengan sangat baik.

\section{Penelitian}

Data yang ada di lapangan, budaya akademik dibidang penelitian meliputi: 1) penelitian yang dilaksanakan dosen; 2) penelitian mahasiswa; dan 3) dosen dan mahasiswa. Hasil kuesioner dengan mengambil sampel 35 orang bahwa budaya akademik bidang penelitian menunjukkan 89.71\%. Hal ini berarti bahwa budaya penelitian berkembang sangat baik. 


\section{Pengabdian kepada Masyarakat}

Hasil penelitian, budaya akademik dibidang pengabdian kepada masyarakat diantaranya: 1) Kuliah Kerja Sosial (KKS); 2) Program Kemitraan Masyarakat (PKM); dan 3) Program Pengembangan Desa Mitra (PPDM). Melalui kuesioner bahwa budaya akademik bidang pengabdian kepada masyarakat seperti pada gambar berikut :

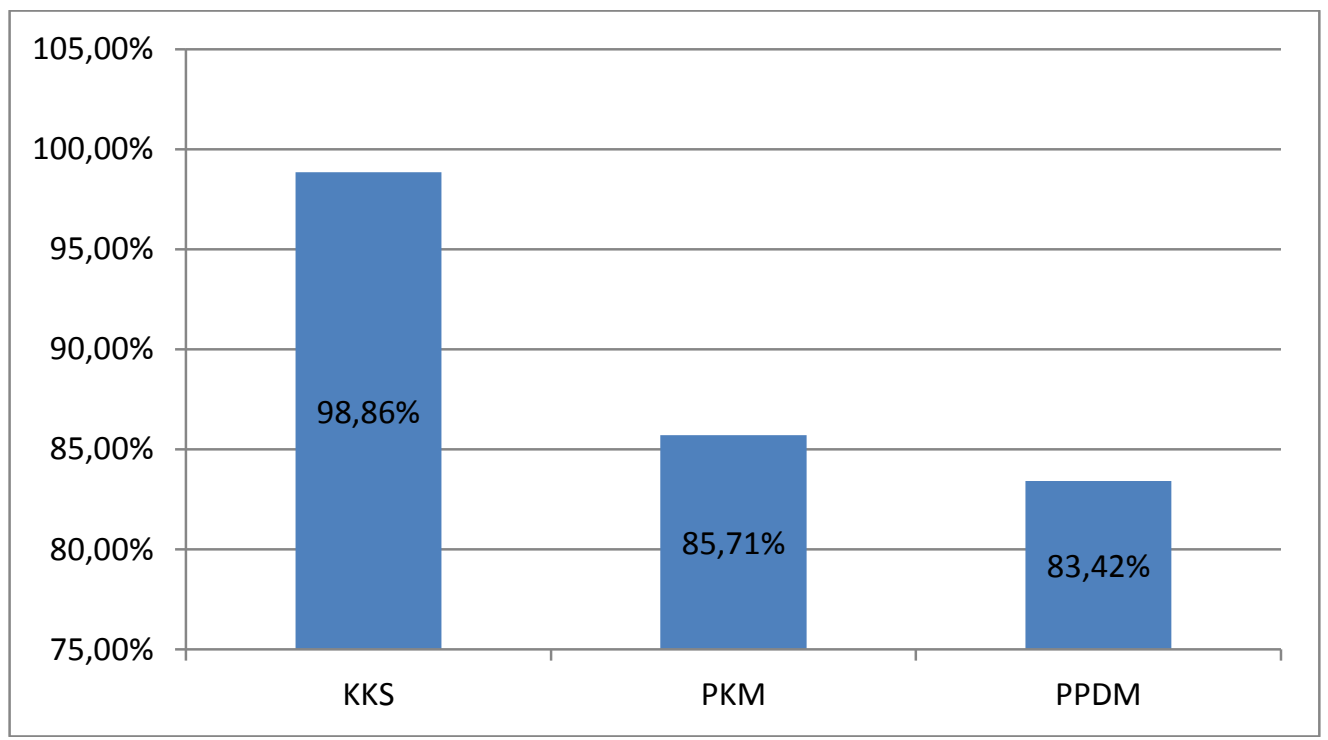

Diagram Budaya Akademik pengabdian kepada masyarakat

Diagram di atas menunjukkan bahwa budaya akademik bidang pengabdian kepada masyarakat rata-rata mencapai 89.33\%. Hal ini menunjukkan bahwa budaya akademik bidang pengabdian kepada masyarakat berkembang dengan sangat baik.

\section{Problematika Pengembangan Budaya Akademik di Fakultas Ilmu Tarbiyah dan Keguruan IAIN Sultan Amai Gorontalo}

Mengembangkan budaya akademik bukanlah tanpa masalah, membutuhkan kreativitas dan inovasi. Perkembangan masyarakat yang semakin komplek menuntut Perguruan tinggi memiliki dan mengembangkan budaya akademik yang dapat membentuk mahasiswa agar memiliki jatidiri dan kompetensi dibidangnya. Berdasarkan hasil penelitian bahwa ada 2 faktor yang menjadi kendala dalam mengembangkan budaya akademik di Fakultas Ilmu Tarbiyah IAIN Sultan Amai Gorontalo, yaitu faktor internal dan eksternal. Faktor internal dimana masih terdapat dosen yang kurang disiplin terhadap frekuensi perkuliahan / tatap muka, budaya membaca dan menulis buku masih rendah baik dosen ataupun mahasiswa. Faktor eksternal, dimana sarana pendukung alat membaca buku-buku digital-ereader di perpustakaan seperti komputer/laptop belum tersedia khusus untuk ruang baca serta minimnya pengadaan bahan pustaka baru setiap tahun.

Menurut Undang-Undang Nomor 43 Tahun 2007, perpustakaan adalah institusi pengelola koleksi karya tulis, karya cetak, dan karya rekam secara 
profesional dengan sistem yang baku guna memenuhi kebutuhan pendidikan, penelitian, pelestarian, informasi, dan rekreasi para pemustaka. Oleh karena itu perlu penataan kembali keberadaan perpustakaan kampus agar pernannya sesuai dengan fungsi memberikan layanan kepada pemustaka, meningkatkan kegemaran membaca, serta memperluas wawasan dan pengetahuan untuk mencerdaskan kehidupan bangsa, memiliki kesadaran informasi yang baik. Kesadaran akan arti penting informasi inilah yang lazim disebut dengan literasi informasi.

\section{Penutup}

Berdasarkan fakta, data hasil penelitian dan pembahasan, maka penulis dapat menguraikan kesimpulan sebagai berikut: Budaya akademik FITK IAIN Sultan Amai Gorontalo berdasarkan pelaksanaan Tri dharma Perguruan Tinggi yaitu: Pendidikan dan pengajaran, meliputi ; 1) kerjasama team teaching antar dosen, dosen dengan mahasiswa dan antar mahasiswa; 2) proses perkuliahan yang terprogram dan terjadwal; 3) budaya membaca dan menghafal; 4) beda buku; dan 5) Workshop/lokakarya/Seminar/ Simposiun/Diskusi Panel. Penelitian, yaitu: 1) penelitian yang dilaksanakan dosen; 2) penelitian mahasiswa; dan 3) dosen dan mahasiswa. Pengabdian kepada masyarakat diantaranya: 1) Kuliah Kerja Sosial (KKS); 2) Program Kemitraan Masyarakat (PKM); dan 3) Program Pengembangan Desa Mitra (PPDM).

Kendala dalam mengembangkan budaya akademik di Fakultas Ilmu Tarbiyah IAIN Sultan Amai Gorontalo, yaitu faktor internal dan eksternal. Faktor internal dimana masih terdapat dosen yang kurang disiplin terhadap frekuensi perkuliahan / tatap muka, budaya membaca dan menulis buku masih rendah baik dosen ataupun mahasiswa. Faktor eksternal, dimana sarana pendukung alat membaca buku-buku digital-e-reader di perpustakaan seperti komputer/laptop belum tersedia khusus untuk ruang baca serta minimnya pengadaan bahan pustaka baru setiap tahun.

Untuk mencapai kondisi yang diharapkan dalam pengembangan budaya akademik di FITK IAIN Sultan Amai Gorontalo perlu adanya kajian dan penelitian yang intensif dan komprehensif dengan berbagai pendekatan yang relevan. Pembinaan bagi mahasiswa yang diarahkan untuk membangun budaya akademik yang kritis dan peka terhadap fenomena sosial. Pengkondisian ini dilakukan dengan penerapan proses pembelajaran berbasis pada permasalahan, penguatan jaringan, peningkatan pembelajaran ekstra melalui penguatan kelembagaan mahasiswa dan membudayakan forum-forum diskusi. Dengan ditunjang hubungan kultural antara dosen dan mahasiwa yang selaras, maka proses pembelajaran tidak hanya dilakukan dalam kelas namun juga diluar kelas secara informal. Disinilah transfer of knowledge and skills berjalan dengan sinergis. Selain peningkatan kapasitas akademis, pengembangan kemahasiswaan juga memiliki aspek peningkatan kualitas iman dan taqwa kepada Tuhan Yang Maha Esa, budi pekerti luhur yang berkepribadian dan berkebudayaan Indonesia, mandiri, maju, tangguh, cerdas, trampil, kreatif serta sehat jasmani dan rohani.

Program literasi dan menghafal al-Qur'an perlu ditetapkan sebagai budaya akademik utama yang menjadi cermin Institut, sehingga masyarakat mengenal IAIN Sultan Amai Gorontalo sebagai lembaga literasi dan penghafal al-Qur'an Dengan program ini mahasiswa bukan hanya sekedar membaca dan menghafal ayat- 
ayatnya, akan tetapi mahasiswa dapat mengambil manfaat dari Al-Qur'an dan mengamalkannya dalam kehidupan sehari-hari.

\section{Daftar Pustaka}

A. Sobirin, Budaya Organisasi, (Yogyakarta: UPP STIM YKPN, 2009).

Alfoart, Rides, Budan dan Mimbar Akademik: http://blogkita.info/budayaakademik-2/ diakses 25 Januari 2019

Another Lost Stories: Pre-Launching: Xiao Yi M1, http.03/ Kamera Mirrorless Versi Murah Mirip Leicahttp://blogkita.info/budaya-akademik-2/ /30 diakses 25 Januari 2019.

Arjun Appadurai, Pemisahan dan Perbedaan dalam Ekonomi Budaya Global". (Jakarta: Dimensi Budaya Globalisas, 1996).

Barnadib, Imam, Kode Etik Akademik: Telaah Deskriptif Awal, (Yogyakarta: Taman Siswa, 2002).

Departemen Pendidikan Nasional, Kamus Besar Bahasa Indonesia, (Jakarta: Balai Pustaka, 2000)

Kaelan, M. S. Pendidikan Pancasila. Edisi 8. (Yogyakarta: Paradigma, 2004).

Keputusan Menteri Pendidikan dan Kebudayaan Republik Indonesia No. 056/U/1994 tentang Pedoman Penyusunan Kurikulum Pendidikan Tinggi dan Penilaian Belajar Mahasiswa

Keputusan Menteri Pendidikan Nasional Republik Indonesia No. 232/U/2000 tentang Pedoman Penyusunan Kurikulum Pendidikan Tinggi dan Penilaian Belajar Mahasiswa

Koentjaraningrat, Pengantar Antropologi, (Jakarta: Rineka Cipta, 2001).

M. Fajar, Mahasiswa dan Budaya Akademik (Bandung: Rineka Cipta, 2002).

Malik Fajar, Budaya Akademik Perguruan Tinggi, http://maknaartikel.blogspot.com/2010/01/budaya-akademik/ survei.html. diakses 25 Januari 2019

Minhaji, Akhmad, Tradisi Akademik di Perguruan Tinggi, (Yogyakarta: SUKA Press, 2013).

Moleong, Lexy J, Metodologi Penelitian Kualitatif (Bandung: Remaja Rosda Karya, 2002).

Muhaimin, et. al. Manajemen Pendidikan: Aplikasinya dalam Penyusunan Rencana Pengembangan Sekolah atau Madrasah, (Jakarta: Kencana, 2010).

Muhajir, Noeng,Filsafat Ilmu, (Yogyakarta: Rake Sarasin, 2001).

Mulyadi, Kepemimpinan Kepala Madrasah Dalam Mengembangkan Budaya Mutu, (Jakarta: Badan Litbang dan Diklat Kemenag RI, 2010).

Mulyana, Deddy dan Jalaluddin Rakhmat. Komunikasi Antarbudaya: Panduan berkomunikasi dengan Orang-Orang Berbeda Budaya. (Bandung: Remaja Rosdakarya, 2006).

Nur Zazin, Gerakan Menata Mutu Pendidikan: Teori dan Aplikasi (Yogyakarta: ArRuzz Media, 2011).

Samudi, "Upaya Meningkatkan Budaya Akademik di Perguruan Tinggi", Materi disampaikan pada acara Seminar Ilmiah di lingkungan Perguruan Tinggi La Tansa Mashiro, hari Jum'at tanggal 23 Maret 2012 di Hall Perguruan Tinggi La 
Tansa Mashiro Rangkasbitung, http://samudi-mpd.blogspot.co.id/, diakses 24-01-2020.

Sugiyono, Metode Penelitian Kombinasi (Mixed Methods), (Bandung, Alfabeta, 2014).

Undang-Undang nomor 12 tahun 2012, tentang Pendidikan Tinggi.

Widyosiswoyo, Supartono, Ilmu Budaya Dasar, (Bogor: Ghalia Indonesia, 2009). 